\title{
多発骨盤骨折の内固定における力学解析 Mechanical Analysis of Multiple Pelvic Fracture with Plate Fixation
}

\author{
○学 野口 愛子（新潟工大） 正 勝山 恵子（新潟工大） 正 笹川 圭右（新潟工大） \\ 正 尾田 雅文（新潟大）塩田 直史（岡山医療センター） \\ 正 寺島 正二郎（新潟工大） 正 原 利昭（新潟工大）
}

Aiko NOGUCHI, Niigata Institute of Technology, 1719 Fuzihashi, Kashiwazaki, Niigata

Keiko KATHUYAMA, Niigata Institute of Technology

Keisuke SASAGAWA, Niigata Institute of Technology

Masafumi ODA, Niigata University, Ikarashi 2-8050, Nishi-ku, Niigata, Niigata

Naofumi SIOTA, Okayama Medical Center, Tamasu 1711-1, Kita-ku, Okayama, Okayama

Shouzirou TERASHIMA, Niigata Institute of Technology

Toshiaki HARA, Niigata Institute of Technology

Key Words: Finite Element Analysis, Pelvic Fracture, Plate Fixation, Pelvic tilt

\section{1. 緒言}

交通事故等では高エネルギー外力が作用し，多発骨折に 至るケースが少なくない。この種の骨折では，複数箇所で 骨が離断することから骨折部にはプレート固定法等が適用 される。骨盤骨折では多様な骨折状態が見られることが多 く，インスツルメンツの選択や固定位置の選定は，医師の 経験や勘に基づいて考慮される場合が多い.

一般的に，骨折の治癒はプレート固定後の多発骨折部 であっても, 骨折面に荷重負荷があると治癒効果が期待で きる.プレートの固定状態が適切でない場合には,「偽関節」 や「プレート破損」が見られた報告もある．更には，高エ ネルギー外傷骨折では，骨癒合に要する期間の遷延や癒合 しない症例も報告されている. 従って, 術前に力学的観点 からインスツルメンツの選択や固定方法を十分に検討する 事が，治療方針の検討や方法を決定する上でも，極めて重 要である。

骨折治癒における有限要素( $\mathrm{FE}$ )解析は単純骨折での報告 が多くあるが(1)，多発骨折でのプレートやスクリュー等に よる固定を対象とした FE 解析例は少ない，そこで，本研 究では, 骨盤の多発骨折時に適用するプレート固定法を解 析対象とし, 骨折治癒の効率化を目指す上で重要なプレー 卜固定部の応力状態を明らかにするため, 骨盤骨折患者の 臨床例を用いた力学解析を行った.

\section{2. 解析方法}

\section{$2 \cdot 1$ 解析対象}

骨盤の両側骨折を受傷し, 骨折部をプレート(Plate)とス クリュー(Screw)による固定法が施術された患者 (女性 75 歳) を対象とした. Fig.1 に示すように, 右恥骨と右仙腸関節骨 折部はロッキング機構の付いたプレートとスクリューで,

一方，右腸骨翼と左恥骨はスクリューで，それぞれ固定さ れている。

\section{$2 \cdot 2$ 有限要素モデルの構築}

患部の X 線 CT 画像を用いて, 3 次元画像編集ソフトウ エア『Mimics』（Version 15.01，Materialise，BE）により骨 盤及びプレート，スクリューそれぞれの形状モデルを作成 した. Fig.1 に示すように，骨折線に沿って厚さ $1 \mathrm{~mm}$ の仮 骨(Callus)を設置することで骨折部を再現し(1)，皮質骨部と して, 骨盤モデル表面に厚さ $1 \mathrm{~mm}$ のシェルを設定した(2). FE メッシュは線形弾性体とし, 要素サイズは約 $2 \mathrm{~mm}$, 要
素総数 $1,042,613$ であった。骨盤骨の物性值は, CT 值に基 づき $E=2017.3 \rho^{2.46}$ ( $\rho$ :骨密度)の式から算出 ${ }^{(2)}$ し, プレート 周囲に生じたメタルアーチファクトによる異常值には, ヤ ング率 700MPa を設定して周囲の骨の状態に近づけた。そ の他の各材料のヤング率とポアソン比は, 皮質骨は $17 \mathrm{GPa}$, 0.3 , 関節軟骨は $15 \mathrm{MPa}, 0.45^{(4)}$, 及びスクリューとプレー トについては, Plate-1 と Screw-1,2 はチタン製で 110GPa, 0.3, Plate-2 はスチール製で $206 \mathrm{GPa}, 0.3$ とした.

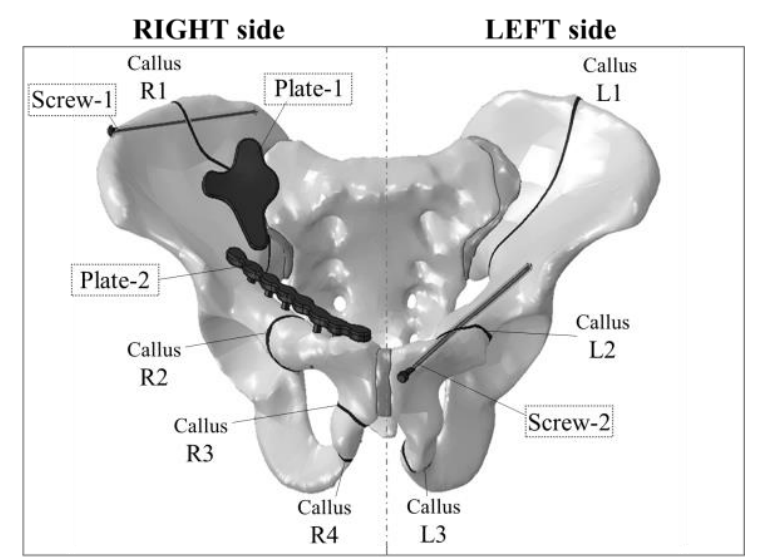

Fig.1 Position of the plates and screws used to fix pelvic fracture and the callus at fracture line

\section{3 解析条件}

有限要素解析ソフト『ABAQUS』(Version 6.12, Simulia, US）を用いて，プレート固定術後の骨盤骨折モデルに有限 要素法による非線形応力解析を行った。境界条件は, 仙骨 上端面の節点を完全固定し, 荷重条件には, 立位での体重 負荷を想定した荷重を寛骨臼に加えた (3). 骨盤一スクリュ 一及びプレート，骨盤一仮骨の間の接触面は結合拘束した (3). 仮骨(Callus)は治癒過程を考慮し, 手術直後のヤング率 は $1 \mathrm{MPa}$ を，骨治瘉の進行した状態では $100 \mathrm{MPa}$ をそれぞ れ設定した ${ }^{(1)}$. 骨折断面間の仮骨のヤング率の設定值を段 階的に増加させることで骨折治瘉過程を想定したときの, 仮骨及びプレートに加わる応力状態の変化を評価した。さ らに, 高齢者の姿勢を考慮し, 骨盤の傾斜角を解析条件に 加えた. 骨盤角度が前傾 $10^{\circ}(-10 \mathrm{deg})$ や後傾 $10^{\circ}(+10 \mathrm{deg})$ での 応力状態を比較した。 


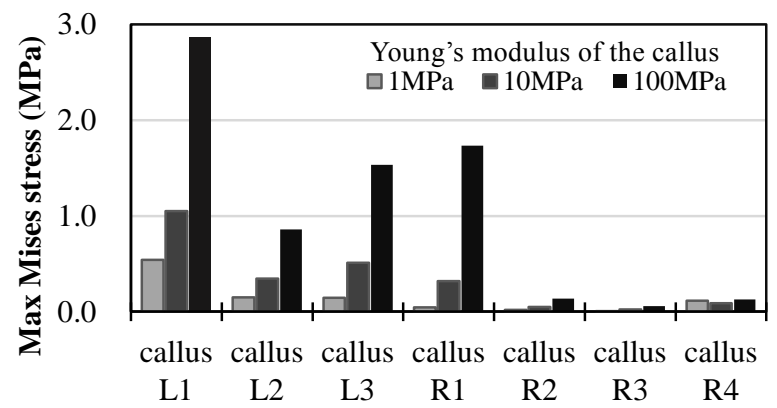

Fig.2 Maximum von Mises stress at the calluses at different healing stages

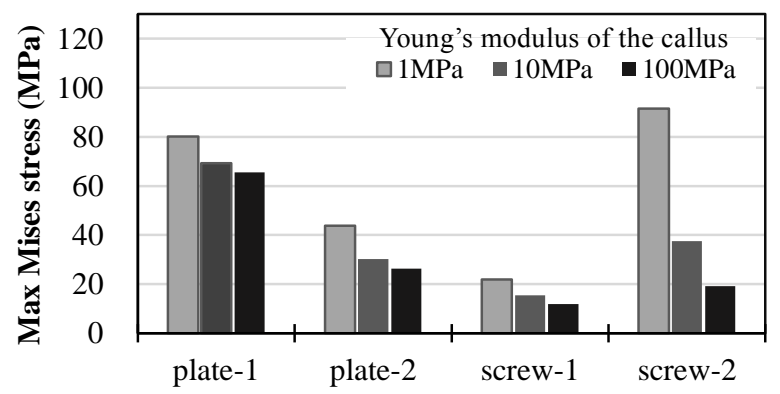

Fig.3 Maximum von Mises stress at the plates \& screws at different healing stages

\section{3. 結果および考察}

解析により，プレート固定術後骨盤骨折モデルでの仮骨 並びにプレートとスクリューに作用したミーゼス応力の最 大值を Fig.2 と Fig.3 にそれぞれ示す.仮骨のヤング率が $1 \mathrm{MPa}$ から $100 \mathrm{MPa}$ に増加するに従い, 応力值の減少を示 した callus-R4 を除くすべての callus で応力值の増加がみら れた，その反面，プレートとスクリューに作用した応力值は， すべてにおいて減少する傾向にあった. 仮骨部の応力状態を 詳しく見てみると, 骨癒合の進行に伴い, 仮骨に加わる圧縮力 および引張力はともに増加しており，特に callus-R1 では引 張力の著しい増加がみられ(Fig.4), 引張力の増加は骨折部 の離断のおそれが考えられる．全体的には圧縮力の増加が 見られることから，骨治癒の進行による荷重伝達の向上が 考えられる. callus-R4 の応力值減少については, callus-R4 がプレートやスクリューによる固定がなされていないこと， ならびに恥骨部の荷重伝達等による影響が考えられる。

高齢者の姿勢を考慮して骨盤の傾斜角度による骨折部へ の影響を検討した。骨盤傾斜を前傾 $10^{\circ}$, 標準 $0^{\circ}$, 後傾 $10^{\circ}$ としたときに callus-R1，R3 および plate-1のそれぞれに生 じた最大ミーゼス応力值を Fig.5 に示す. 骨盤傾斜が前傾 から後傾になるにつれて, callus-R1 を含む骨治療の進行が 良好にみられた仮骨部でミーゼス応力值が高くなった。ま た plate-1 を含むプレートおよびスクリューでのミーゼス 応力值も高くなる傾向にあった。ところが，骨癒合し難く 応力值の低かった恥骨部の callus-R3 での応力值はあまり 変化せず，骨盤傾斜の影響は小さい傾向にあった。骨盤が 後傾すると恥骨部を除く仮骨に加わる応力值が高くなるこ とから，骨盤傾斜 $0^{\circ}$ での解析よりも高齢者の姿勢を考慮 した後傾姿勢での解析が重要であると考えられる.

以上のことから，仮骨のヤング率が増加するに従い，骨 による荷重伝達の向上がみられ，プレートとスクリューへ の負荷は減少しているため, 骨治癒が良好に進展するもの と推察できる。一方，恥骨部においては，負荷による応力

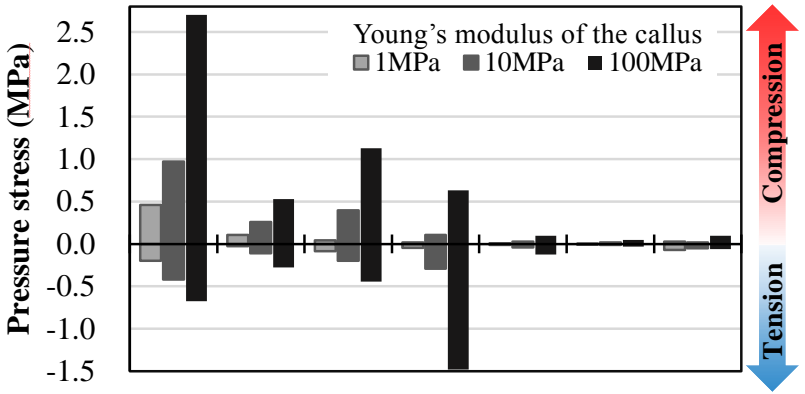

callus callus callus callus callus callus callus

$\begin{array}{lllllll}\text { L1 } & \text { L2 } & \text { L3 } & \text { R1 } & \text { R2 } & \text { R3 } & \text { R4 }\end{array}$

Fig.4 Variation of pressure stress at the calluses at different healing stages
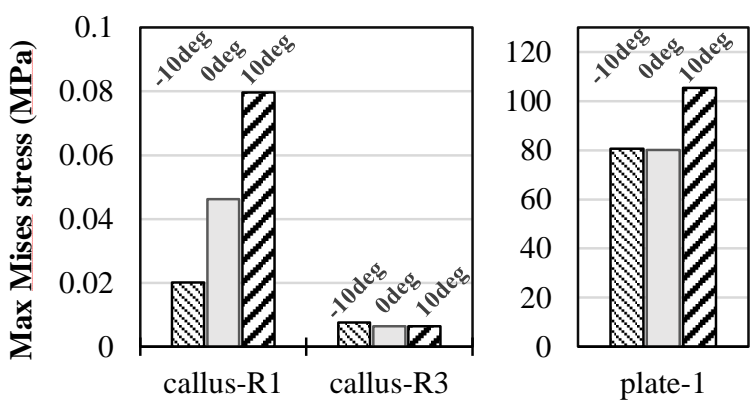

Fig.5 Change of maximum von Mises stress at the calluses and plate for postures from anterior (-10deg) to posterior (+10deg) pelvic tilts (Young's modulus of the callus is $1 \mathrm{MPa})$

值が低く, 応力值の推移も他の領域と異なる結果となった. これらの解析結果から骨片間圧力が低い部分は骨癒合が進 行し難いことが考えられ, 恥骨部が結合していなかったと いう患者症例の状況と一致していた。したがって，骨折部 の応力状態を解析することで, 骨折部の骨癒合の進展をシ ミュレーションできることが示唆された。

\section{4. 結言}

骨盤の多発骨折時に適用されるプレート固定法を解析対 象とし，骨折治癒の効率化を目指す上で重要なプレートお よび骨盤固定部の応力状態を明らかにするため, FE 解析を 行った。骨治癒を想定した解析を行ったところ，骨治癒の 進行により仮骨部の応力值増加，プレートとスクリューへ の作用応力の減少がみられ，骨治癒により骨折部の体重支 持が可能になることが示唆された。また実際に骨癒合が進 行し難い恥骨部の解析結果は臨床例との一致を示した。こ のことから骨折固定部の応力状態を解析すると骨癒合のシ ミュレーションが可能であることが示唆され，さらに骨盤 姿勢を考慮することで，高齢者を対象とした詳細な解析が 可能となる.

\section{参考文献}

(1) H. Fouad: Medical Engineering \& Physics 33, 2011, pp.456463.

(2) M. Dalstra et al.: Transactions of ASME 117, 1995, pp.272278.

(3) J. Böhme et al.: Clinical Biomechanics 27, 2012, pp.872-878.

(4) X. Zhao et al.: Journal of Orthopaedic Science 15, 2010, pp.632-640. 